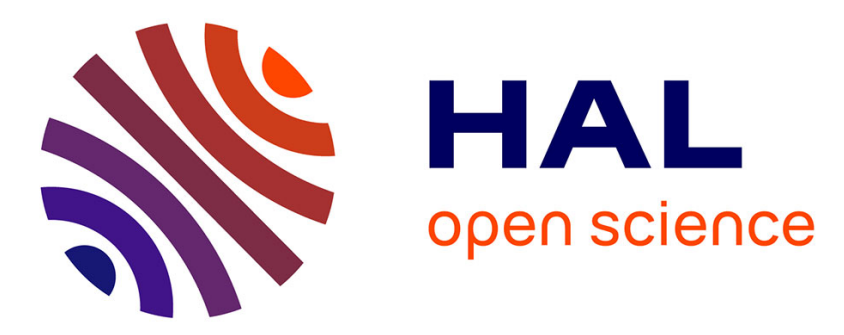

\title{
Ecological changes in historically polluted soils: Metal(loid) bioaccumulation in microarthropods and their impact on community structure
}

Annabelle Austruy, Christophe Laplanche, S Mombo, Camille Dumat, F Deola, Charles Gers

\section{To cite this version:}

Annabelle Austruy, Christophe Laplanche, S Mombo, Camille Dumat, F Deola, et al.. Ecological changes in historically polluted soils: Metal(loid) bioaccumulation in microarthropods and their impact on community structure. Geoderma, 2016, 271, pp.181-190. 10.1016/j.geoderma.2016.02.011 . hal01346508

\section{HAL Id: hal-01346508 \\ https://hal.science/hal-01346508}

Submitted on 19 Jul 2016

HAL is a multi-disciplinary open access archive for the deposit and dissemination of scientific research documents, whether they are published or not. The documents may come from teaching and research institutions in France or abroad, or from public or private research centers.
L'archive ouverte pluridisciplinaire HAL, est destinée au dépôt et à la diffusion de documents scientifiques de niveau recherche, publiés ou non, émanant des établissements d'enseignement et de recherche français ou étrangers, des laboratoires publics ou privés. 


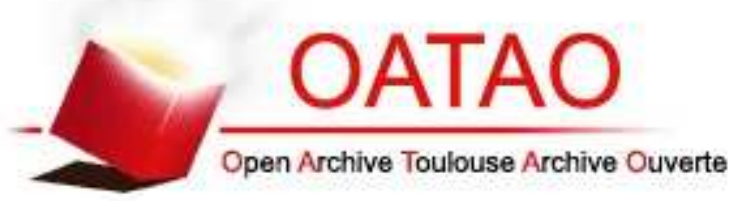

\section{Open Archive TOULOUSE Archive Ouverte (OATAO)}

OATAO is an open access repository that collects the work of Toulouse researchers and makes it freely available over the web where possible.

This is an author-deposited version published in : http://oatao.univ-toulouse.fr/ Eprints ID : 15976

To link to this article : DOI : 10.1016/j.geoderma.2016.02.011

URL : http://dx.doi.org/10.1016/j.geoderma.2016.02.011

To cite this version : Austruy, Annabelle and Laplanche, Christophe and Mombo, S and Dumat, Camille and Deola, F and Gers, Charles Ecological changes in historically polluted soils: Metal(loid)

bioaccumulation in microarthropods and their impact on community structure. (2016) Geoderma, vol. 271. pp. 181-190. ISSN 00167061

Any correspondence concerning this service should be sent to the repository administrator: staff-oatao@ listes-diff.inp-toulouse.fr 


\title{
Ecological changes in historically polluted soils: Metal(loid) bioaccumulation in microarthropods and their impact on community structure
}

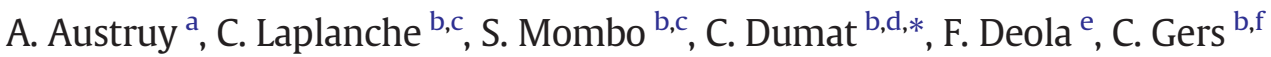 \\ a Institut Ecocitoyen pour la Connaissance des Pollutions - Centre de Vie la Fossette, RD 268, 13270 Fos-sur-Mer, France \\ ${ }^{\mathrm{b}}$ Université de Toulouse, INP-ENSAT - Av de l'Agrobiopole, P.O. Box 107, Auzeville-Tolosane, 31326, Castanet-Tolosan, France \\ c UMR 5245 CNRS-INP-UPS EcoLab, Avenue de l'Agrobiopole, P.O. Box 107, Auzeville-Tolosane, 31326 Castanet-Tolosan, France \\ d CERTOP, UMR5044, Université Toulouse Jean Jaurès - TOULOUSE II, 5 Allée Antonio Machado, 31058 Toulouse Cedex 9, France \\ e STCM, Société de Traitements Chimiques des Métaux, 30 Avenue Fondeyre, 31200 Toulouse, France \\ ${ }^{\mathrm{f}}$ Université de Toulouse, CNRS-INP-UPS UMR 5245 EcoLab - 118 Route de Narbonne, 31062 Toulouse, France
}

Keywords:

Microarthropod communities

Springtails

Mites

Metal(loid) pollution

Bioaccumulation

\begin{abstract}
A B S T R A C T
Soil pollution by persistent metal(loid)s present environmental and sanitary risks. While the effects of metal(loid)s on vegetation and macrofauna have been widely studied, their impact on microarthropods (millimetre scale) and their bioaccumulation capacity have been less investigated. However, microarthropods provide important ecosystem services, contributing in particular to soil organic matter dynamics.

This study focussed on the impact of metal(loid) pollution on the structure and distribution of microarthropod communities and their potential to bioaccumulate lead $(\mathrm{Pb})$. Soil samples were collected from a contaminated historical site with a strong horizontal and vertical gradient of $\mathrm{Pb}$ concentrations. Microarthropods were extracted using the Berlese method.

The field experiments showed that microarthropods were present even in extremely polluted soils $\left(30,000 \mathrm{mg} \mathrm{Pb} \mathrm{kg}^{-1}\right)$. However, while microarthropod abundance increased with increasing soil $\mathrm{C} / \mathrm{N}$ content $\left(R^{2}=0.79\right)$, richness decreased with increasing pollution. A shift in the community structure from an oribatid-to a springtail-dominated community was observed in less polluted soils $\left(\mathrm{R}^{2}=0.68\right)$. In addition, $\mathrm{Pb}$ bioamplification occurred in microarthropods, with higher $\mathrm{Pb}$ concentrations in predators than in detritivorous microarthropods. Finally, the importance of feeding and reproductive ecological traits as potentially relevant descriptors of springtail community structures was highlighted. This study demonstrates the interest of microarthropod communities with different trophic levels and ecological features for evaluating the global environmental impact of metal(loid) pollution on soil biological quality.
\end{abstract}

\section{Introduction}

At the global scale, historical soil pollution by persistent metal(loid)s presents environmental and sanitary risks (Schreck et al., 2011; Levêque et al., 2013; Dumat and Austruy, 2014; Kpan et al., 2014; Xiong et al., 2014; Levêque et al., 2015). While the harmful effects of metal(loid)s on vegetation and soil macrofauna have been widely studied (chapter 10 of Hopkin, 1997; Reddy et al., 2005; Sharma and Dubey, 2005; Gichner et al., 2008; Austruy et al., 2013), their impact on microarthropod communities (millimetre scale) and their bioaccumulation capacity have been less investigated. However, microarthropods contribute significantly to soil organic matter dynamics, for example by improving leaf

* Corresponding author at: INP-ENSAT Av. Agrobiopole 31300 Auzeville, CERTOP, UMR 5044 - CNRS, Maison de la Recherche, Université Toulouse - Jean Jaurès, 5, Allée Antonio Machado, F-31058 Toulouse Cedex 9, France.

E-mail address: camille.dumat@ensat.fr (C. Dumat). litter decomposition and organic matter recycling (Chagnon et al., 2000; Gobat et al., 2010; Van Eekeren et al., 2009). Indeed, soil microarthropods contribute directly to decomposition processes of 5 to $10 \%$ of fresh organic matter (Sechi et al., 2014). Feeding directly on decaying materials and soil fungi, microarthropods provide an early indication of ecosystem health and therefore have an important role in functional ecology (Coleman et al., 2004; Van Eekeren et al., 2009) and associated ecosystem services (Lavelle et al., 2006; section 1.3 of Wall et al., 2013). Moreover, a significant proportion of the carbon consumed by microarthropods originates from the rhizosphere (Hishi and Takeda, 2008). Springtails (Collembola) have been used as an ecotoxicological model species due to their high sensitivity to various environmental changes (Ardestani et al., 2014). Metal(loid) bioaccumulation in springtails can be an efficient indicator of the exposure level in polluted areas. Moreover, the ecological traits are dependent on ecosystem characteristics and could be used to interpret the distribution of the springtail community as a function of the physico-chemical parameters and metal pollution of soil. Indeed, 
springtail diet is dependent on the nutritional quality of the soil. The breeding patterns might allow a better understanding of the mechanisms of distribution and development of these species (Salmon et al., 2014). This is particularly useful in the case of taxa with substantial functional redundancy like Collembola.

According to Van Gestel and Koolhaas (2004), the main route for metal(loid) uptake by microarthropods is the soil solution, which contains fungi and which is in contact with the soil organic matter. Soil solution is actually considered as a major exposure pathway for the majority of pedofauna. Metal(loid) bioaccumulation is a complex process which includes absorption, intrinsic distribution, storage, and excretion (Wang and Rainbow, 2008). Indeed, the type of metal(loid) and soil physico-chemical properties as well as organism physiology can affect metal(loid) bioaccumulation (Lanno et al., 2004; Ardestani and Van Gestel, 2013). Likewise, metal bioavailability is mainly influenced by soil $\mathrm{pH}$ and the amount of soil organic matter (Levêque et al., 2013) or by the presence of various ligands in the soil solution (Shahid et al., 2014). Metal bioaccumulation in microarthropods could therefore be a relevant measure of metal bioavailability and thus of the overall soil ecotoxicity.

In a global scientific context, our research hypothesis was that metal(loid) pollution could modify microarthropod ecology. The two main objectives of this study were therefore to: (1) evaluate the influence of historical metal(loid) soil pollution on microarthropod community structure, and notably springtail population, and (2) compare bioconcentration factors across microarthropod trophic levels. The study was carried out in a fallow meadow located near a metal treatment factory. A previous study from Levêque et al. (2015) documented the existence of a pollution gradient in this area due to the airborne emissions from the factory, thus providing an interesting site to investigate the potential effects of metal(loid)s on soil fauna biodiversity and bioaccumulation. We demonstrate the relevance of microarthropod communities and bioaccumulation as bioindicators of soil pollution and ecotoxicity.

\section{Materials and methods}

\subsection{Field sampling}

Soils were sampled in a fallow meadow located close to a metal treatment factory (Bazoches-les-Gallerandes, Region Centre, France). The study area is 4.5 ha. The level of metal contamination steeply decreases with increasing distance from the factory (Levêque et al., 2015). Soil samples were taken along a linear transect similar to that in the previous study (distances to the factory: $10,30,50,70,95,130$, and $140 \mathrm{~m}$ ) (Fig. 1). In the present study, 10 soil samples were taken at each distance for further microarthropod analyses.

For the analysis of physico-chemical parameters and metal concentrations, three soil samples were sampled at each distance. For each distance, the three samples were then pooled and homogenised to constitute a composite sample used for the analysis. The results were published by Levêque et al. (2015). Physico-chemical soil parameters $(\mathrm{pH}$, total organic carbon, total nitrogen, carbon nitrogen ratio $(\mathrm{C} / \mathrm{N})$, organic matter) are summarised in Table 1 . Soil pH is alkaline. Organic matter, total nitrogen, and $\mathrm{C} / \mathrm{N}$ decreased with increasing distance to the factory (Levêque et al., 2015). Table 2 shows metal(loid) contents ( $\mathrm{Zn}, \mathrm{Cu}, \mathrm{As}, \mathrm{Cd}, \mathrm{Sb}$, and $\mathrm{Pb}$ ) in soil. Close to the factory $(10 \mathrm{~m})$, the total metal concentration was extremely high notably due to high $\mathrm{Pb}$ and $\mathrm{Cd}$ concentrations (29,600 and $314 \mathrm{mg} \mathrm{kg}^{-1}$, respectively) and to a lesser extent $\mathrm{Sb}, \mathrm{Cu}, \mathrm{As}$, and $\mathrm{Zn}$. Concentrations decreased with increasing distance to the factory; $\mathrm{Pb}$ was the pollutant found at the highest concentrations at the study site, ranging from $29,600 \mathrm{mg} \mathrm{Pb} \mathrm{kg}^{-1}$ ( $10 \mathrm{~m}$ from the factory) to $468 \mathrm{mg} \mathrm{Pb} \mathrm{kg}^{-1}$ $(140 \mathrm{~m})$. Observed changes in agronomic parameters were induced by bio-physicochemical modifications.

\subsection{Microarthropod extraction and identification}

Ten samples were taken at each distance in the organic horizon including the litter, using a corer of $7 \mathrm{~cm}$ in diameter with a volume of $500 \mathrm{~cm}^{3}$ and at a depth of $6.5 \mathrm{~cm}$ (Gobat et al., 2010; Fountain and Hopkin, 2005). Soil samples were put in Berlese Tullgren funnels (Berlese, 1905; Edward and Fletcher, 1971) for 10 days for microarthropod extraction. Soil samples were weighed before and after desiccation on the Berlese funnels to estimate soil moisture. Soil moisture varied between 10 and 20\%. Mesofauna was collected in a $70 \%$ ethanol (96\% Fisher chemical diluted with milliQ water). Microarthropods were identified under a binocular microscope, at the species scale for springtails (Massoud, 1967; Rusek, 1971; Arbea and Jordana, 1997; Bretfeld, 1999; Potapov, 2001; Thibaud et al., 2004) and at a lower scale for mites (oribatid or gamasid) and other microarthropods (Coineau et al., 1997). Springtails and oribatid mites are detritivorous and gamasid mites are predators. For each springtail species, species code, feeding traits (sucker/shredder), reproduction traits (standard, standard-to-explosive, explosive, parthenogenesis), vertical distribution according to Gisin (1943), and total count in the soil samples are shown in Table 3 (Hopkin, 1997). The determining of springtail reproduction modes was performed from work of Czarnetzki and Tebbe (2004) and Tully and Ferriere (2008). The diet of springtails (sucker/shredder) was defined from the shape of the mouthparts notably maxillar (Chen et al., 1997; Santorufo et al., 2014a, 2014b; Hoskins et al., 2015). In this study, the species having 'suctorial' mouthparts were called sucker and the ones having big 'grinding' mouthparts were called grinder.

\subsection{Analysis of metal(loid) content in microarthropods}

Intracorporeal metal(loid) concentrations were measured for each of the 3 microarthropod groups (springtails, oribatid mites, and gamasid mites). Microarthropod samples (10 for each distance and group) were pooled (into 3 samples) in order to obtain a sufficient amount of biological material for metal analysis. As a summary, 63 samples were gathered for metal content analysis (7 distances, 3 microarthropod groups, 3 replicates). The dry weight of microarthropod samples was measured with a micro analytical balance (Mettler Toledo AT21 Comparator). Acid digestion with $\mathrm{HNO}_{3}$ and $\mathrm{H}_{2} \mathrm{O}_{2}$ was used to mineralise microarthropod samples, which were then diluted with milliQ water for analysis by ICP-MS (Bur et al., 2010, 2012). The quality of the dissolution procedure was verified for each sample series using international reference materials (TORT-2, Lobster Hepatopancreas) and blanks. Measured values for reference materials did not exceed $10 \%$ of the certified value.

\subsection{Calculation of soil toxic units and bioaccumulation factors in microarthopods}

Metal concentrations were compared to those found in other soils as well as to standard values for unpolluted soils (Table 2 ). On the one hand, we used the values representing the average metal contents measured in the agricultural soils of the Midi-Pyrénées region for calcareous and non-calcareous soils (Réseau de Mesures de la Qualité des Sols, Redon et al., 2013). On the other hand, we used the impact statement values for sensitive areas (VCI) determined by the BRGM (2002), which is a threshold value for proven pollution.

To determine the origin of metals in soil surface horizons, the Enrichment Factor (EF) was calculated for each metal. Scandium (Sc) was chosen as the reference element (Eq. (1)), according to several criteria developed in Sterckeman et al. (2006) and N'Guessan et al. (2009). The deep soil horizon was used as the reference material. An EF value exceeding 1 theoretically indicates anthropogenic input. In order to account for uncertainties in the comparison process, 


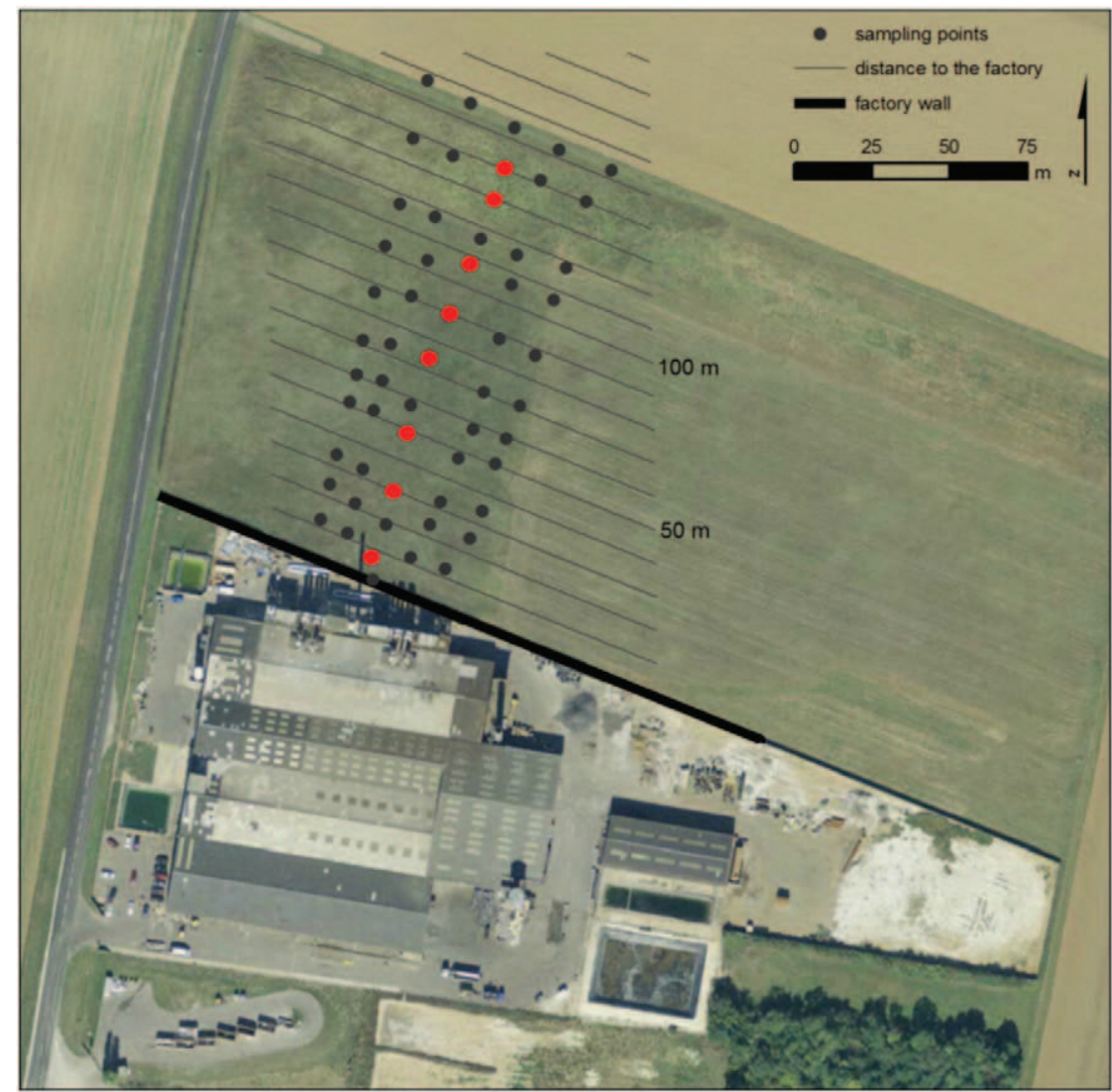

Fig. 1. Map of the study site: lead recycling smelter in Bazoches-les-Gallerandes and the experimental plot. The sampling is performed on the transects indicated with red points from 10 to $140 \mathrm{~m}$ to the smelter courtyard.

a value greater than 2 was considered here to indicate significant soil contamination (Hernandez et al., 2003).

The EF was calculated as follows:

$\mathrm{EF}=([\text { metal }] /[\mathrm{Sc}])_{\text {surface horizon }} /([\text { metal }] /[\mathrm{Sc}])_{\text {deep horizon }}$

The transfer of metals from soil to microarthropods is evaluated via the bioaccumulation factor (BCF). BCF is the ratio between metal concentration in microarthropods and concentration in soil (Eq. (2)).

$\mathrm{BCF}=[\text { metal }]_{\text {microarthropods }} /[\text { metal }]_{\text {soil }}$

\subsection{Statistical analyses}

Microarthropod counts for each soil sample were distributed into four groups (springtails, oribatid mites, gamasid mites, and other microarthropods) and springtail counts were then split into 18 species. For comparative purposes, microarthropod counts were normalised

Table 1

Physico-chemical parameters in upper horizon of soil in function of distance to factory.

\begin{tabular}{|c|c|c|c|c|c|}
\hline $\begin{array}{l}\text { Distance to } \\
\text { factory }\end{array}$ & $\begin{array}{l}\text { Organic } \\
\text { matter }\end{array}$ & $\begin{array}{l}\text { Total organic } \\
\text { carbon }\end{array}$ & $\begin{array}{l}\text { Total } \\
\text { nitrogen }\end{array}$ & \multirow[t]{2}{*}{$\mathrm{C} / \mathrm{N}$} & \multirow[t]{2}{*}{$\mathrm{pH}$} \\
\hline $\mathrm{m}$ & \multicolumn{3}{|l|}{$\mathrm{g} \mathrm{kg}^{-1}$} & & \\
\hline 10 & 59.0 & 34.1 & 2.71 & 12.6 & 7.90 \\
\hline 30 & 53.0 & 30.7 & 2.59 & 11.9 & 8.26 \\
\hline 50 & 55.1 & 31.8 & 2.52 & 12.6 & 8.36 \\
\hline 70 & 34.8 & 20.1 & 1.72 & 11.7 & 8.34 \\
\hline 95 & 43.7 & 25.3 & 2.07 & 12.2 & 8.21 \\
\hline 130 & 34.1 & 19.7 & 1.70 & 11.6 & 8.21 \\
\hline 140 & 24.8 & 14.3 & 1.35 & 10.6 & 8.34 \\
\hline
\end{tabular}

with respect to soil dry weight resulting in microarthropod densities (number of individuals per $\mathrm{kg}$ DM of soil).

Variations of microarthropod density and springtail Pb BCF as a function of distance and/or group were investigated through one-way and two-way analyses of variance (ANOVA). The normality and homoscedasticity of ANOVA residuals were verified using Shapiro-Wilk (SW) and Brown-Forsythe (BF) tests, respectively. Appropriate transformations (power, $\log$ ) were used to satisfy the normality and homoscedasticity requirements of the ANOVA testing procedure. Pairwise differences were later investigated through Tukey multiple comparison tests.

Prospective dissimilarities in the springtail community structure as a function of the distance to the factory were investigated by correspondence analyses (CA). CA is an ordination method, such as principal component analysis, which preserves the chi-squared distance between rows and columns of frequency tables. In our case, the springtail density data table was turned into a proportion table by dividing the density of

Table 2

Metal concentrations in upper horizon of soil in function of distance to factory.

\begin{tabular}{|c|c|c|c|c|c|c|c|}
\hline \multirow{2}{*}{$\begin{array}{l}\text { Distance to } \\
\text { factory (m) }\end{array}$} & $\mathrm{Pb}$ & $\mathrm{Zn}$ & $\mathrm{Cu}$ & As & $\mathrm{Cd}$ & $\mathrm{Sb}$ & $\mathrm{TU}^{\mathrm{a}}$ \\
\hline & \multicolumn{7}{|l|}{$\mathrm{mg} \mathrm{kg}{ }^{-1}$} \\
\hline 10 & $29,600.0$ & 527.1 & 160.0 & 114.3 & 314.5 & 959.3 & 3211.7 \\
\hline 30 & 3700.0 & 127.0 & 46.5 & 21.5 & 20.2 & 118.6 & 331.6 \\
\hline 50 & 4530.0 & 98.8 & 39.7 & 19.5 & 16.3 & 85.7 & 370.9 \\
\hline 70 & 1590.0 & 86.4 & 31.8 & 16.6 & 9.0 & 58.2 & 145.7 \\
\hline 95 & 1290.0 & 73.0 & 22.6 & 18.0 & 5.9 & 36.1 & 112.9 \\
\hline 130 & 1030.0 & 46.4 & 17.2 & 13.5 & 2.5 & 18.9 & 81.4 \\
\hline 140 & 468.0 & 51.0 & 14.8 & 12.5 & 1.8 & 11.5 & 40.9 \\
\hline $\begin{array}{l}\text { Geochemical } \\
\text { background }^{\mathrm{b}}\end{array}$ & $<30$ & $75-150$ & $1-20$ & $1-25$ & $0.02-0.50$ & - & \\
\hline
\end{tabular}

a Toxic units (TU) for all metals except Sb.

b Gis Sol, 2011 
Table 3

Name, reference, code, feeding trait (percentage of individuals in each class; sucker: 31.6\%; grinder: 68.4\%), reproduction trait (standard: 55.1\%; standard to explosive: 35.7\%; explosive: 7.1\%; parthenogenesis: 2.1\%), vertical distribution (epiedaphic: 32.1\%; hemiedaphic: 58.2\%; euedaphic: 9.7\%), and counts for all springtail species. *Rare species (Fse, Opa, and Sni).

\begin{tabular}{|c|c|c|c|c|c|c|}
\hline Name & Reference & Code & Feeding & Reproduction & Distribution & Count \\
\hline Brachystomella parvula & Schaffer (1896) & Bpa & Sucker & Standard & Hemiedaphic & 176 \\
\hline Ceratophysella armata & Nicolet (1842) & Car & Grinder & Explosive & Hemiedaphic & 72 \\
\hline Desoria olivacea & Tullberg (1871) & Dol & Grinder & Standard to explosive & Hemiedaphic & 100 \\
\hline Entomobrya lanuginosa & Nicolet (1842) & Ela & Grinder & Standard & Epiedaphic & 52 \\
\hline Entomobrya multifasciata & Tullberg (1871) & Emu & Grinder & Standard to explosive & Epiedaphic & 73 \\
\hline Folsomia sensibilis & Kseneman (1934) & Fse & Grinder & Standard & Euedaphic & $2^{*}$ \\
\hline Orogastrura parva & Gisin (1949) & Opa & Grinder & Explosive & Hemiedaphic & $2^{*}$ \\
\hline Isotoma viridis & Bourlet (1839) & Ivi & Grinder & Standard to explosive & Epiedaphic & 34 \\
\hline Lepidocyrtus cyaneus & Folsom (1932) & Lcy & Grinder & Standard & Hemiedaphic & 16 \\
\hline Lepidocyrtus lanuginosus & Gmelin (1788) & Lla & Grinder & Standard to explosive & Hemiedaphic & 86 \\
\hline Mesaphorura krausbaueri & Boerner (1901) & Mkr & Grinder & Parthenogenesis & Euedaphic & 22 \\
\hline Pseudosinella alba & Packard (1873) & Pal & Grinder & Standard to explosive & Euedaphic & 32 \\
\hline Protaphorura armata & Tullberg (1869) & Par & Grinder & Standard to explosive & Euedaphic & 45 \\
\hline Pseudachorutes palmiensis & Boerner (1903) & Ppa & Sucker & Standard & Hemiedaphic & 153 \\
\hline Sminthurinus elegans & Fitch (1862) & Sel & Grinder & Standard & Epiedaphic & 16 \\
\hline Sminthurinus niger & Lubbock (1870) & Sni & Grinder & Standard to explosive & Epiedaphic & $1^{*}$ \\
\hline Sphaeridia pumilis & Krausbauer (1898) & Spu & Grinder & Standard & Epiedaphic & 123 \\
\hline Stenacidia violacea & Reuter (1881) & Svi & Grinder & Standard & Epiedaphic & 35 \\
\hline
\end{tabular}

each cell by overall density. The chi-squared distance between two sites (rows) quantifies the dissimilarity between the community structures found at these sites. Such a measure excludes double-zeros from the calculations - that is to say the absence of some species at two sites is not accounted for when computing the similarity between these sites - and is insensitive to the presence of over-abundant species. Conversely, the chi-squared distance between two species (columns) quantifies the dissimilarity between the spatial distributions of these two species. Statistical computations were carried out with R software version 3.0.2 (R Core Team, 2014).

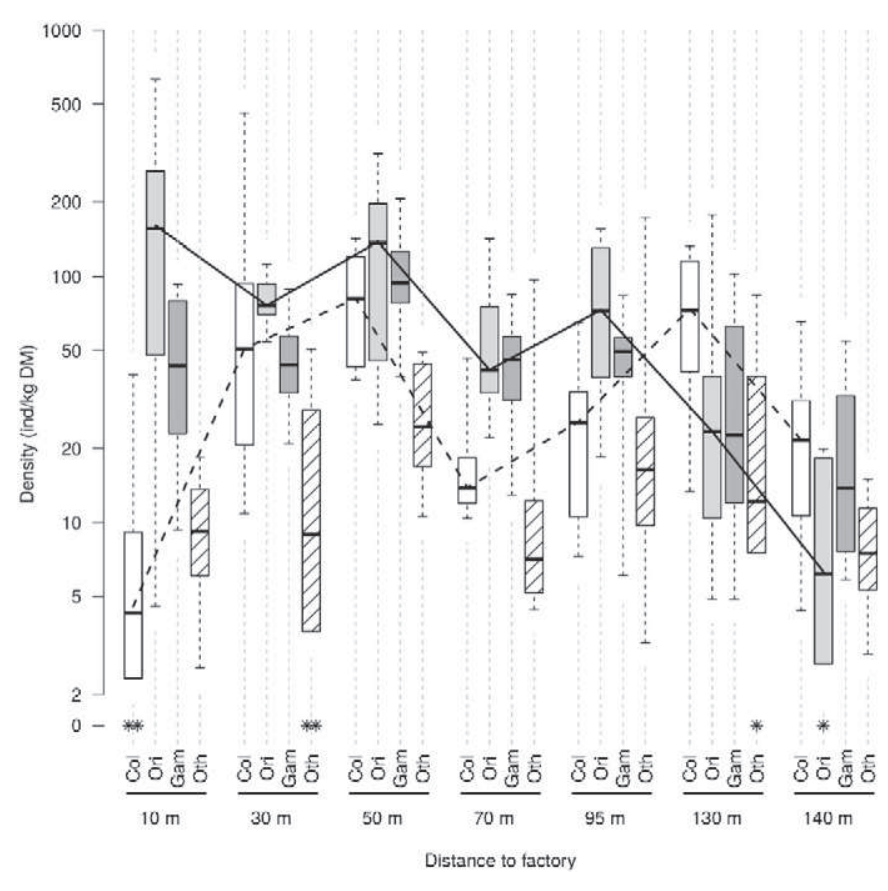

Fig. 2. Microarthropod density in soil with respect to distance to factory: springtail (Col; in white), oribatid mites (Ori; light grey), gamasid mites (Gam; dark grey), and other microarthropods (Oth; white, hatched). Microarthropod densities - microarthropod counts normalised against soil dry weight - are represented as box-and-whisker plots (median, upper and lower quartiles, and maximum values; 10 data samples per box). The detritivorous community shifts from an oribatid mite (median density highlighted with a solid line) dominated to a springtail-dominated (dashed line) community with increasing distance from the factory. Some groups were not found in six soil samples, leading to null densities, highlighted by stars.

\section{Results}

\subsection{Microarthropod community structure}

Microarthropod densities are illustrated in Fig. 2. There was a significant change in total microarthropod density - sum of springtails, oribatid and gamasid mites, and other microarthropods densities associated with the distance to the factory (1-way ANOVA on log transformed total densities; distance: $\mathrm{p}<10^{-5}$; $\mathrm{SW}: \mathrm{p}=0.95$; BF: $\mathrm{p}=0.09$ ) due to a higher density at $50 \mathrm{~m}$ and a lower density at $140 \mathrm{~m}$ (Tukey; significant differences at the 1\% level: $140-10$, 140-30, 140-50, 140-95; additional significant differences at the 5\% level: $70-50,130-50)$. The total microarthropod density appears to be related to the $\mathrm{C} / \mathrm{N}$ ratio in soil, as suggested by the significant linear increase in density with $\mathrm{C} / \mathrm{N}$ (linear regression on average densities; slope: $\mathrm{p}=0.0077 ; \mathrm{R}^{2}=0.79$; Fig. $\mathrm{S} 1$ ).

The structure of microarthropod groups with respect to the distance to the factory is not trivial with a strong distance $\mathrm{x}$ group interaction (2-way ANOVA on log transformed densities; distance: $\mathrm{p}<10^{-15}$; group: $\mathrm{p}<10^{-15}$; distance $\times$ group: $\mathrm{p}<10^{-8}$; $\mathrm{SW}: \mathrm{p}=0.07$; $\mathrm{BF}$ : $\mathrm{p}=0.015$; Fig. 2 ). There was a shift in the detritivorous community structure from an oribatid mite-dominated community at a short distance $(10 \mathrm{~m})$ to a springtail-dominated community at larger distances ( 130 and $140 \mathrm{~m}$ ) as indicated by a significant negative relationship between the proportions of oribatid mites and springtails (linear regression on 0.7 power transformed proportions; slope: $\mathrm{p}<10^{-12}, \mathrm{R}^{2}=0.68$, Fig. $3 \mathrm{~A}$ ). The overall proportion of detritivorous microarthropods was equal for all distances (2-way ANOVA on 0.7 power transformed proportions; distance: $\mathrm{p}=0.14$; $\mathrm{SW}: \mathrm{p}=0.38$; $\mathrm{BF}: \mathrm{p}=0.068$; samples with null densities were discarded) with significant differences between the proportion of oribatid mites and springtails (group: $\mathrm{p}<10^{-5}$; distance $\mathrm{x}$ group: $\mathrm{p}<10^{-15}$ ) due to a higher proportion of oribatid mites at $10 \mathrm{~m}$ (Tukey; $\mathrm{p}<10^{-12}$ ), $70 \mathrm{~m}$ ( $p=0.00017), 95 \mathrm{~m}(\mathrm{p}=0.000020)$, and a higher proportion of springtails at $130 \mathrm{~m}(\mathrm{p}=0.000036)$ and $140 \mathrm{~m}(\mathrm{p}=0.00046)$. The gamasid mite density was proportional to the detritivorous densities on a $\log$-log scale (linear regression on log transformed densities; intercept: $\mathrm{p}=0.09$; slope: $\mathrm{p}<10^{-12} ; \mathrm{R}^{2}=0.54$; Fig. $3 \mathrm{~B}$ ).

In summary, microarthropod density increased linearly with the $\mathrm{C} / \mathrm{N}$ ratio of soil. The total proportion of detritivorous microarthropods (springtails and oribatid mites) was identical in high- and low-polluted soils with a shift from an oribatid mite dominated community in highpolluted soils to a springtail-dominated community in low-polluted soils. The density of predator microarthropods (gamasid mites) was proportional to the available stock of detritivorous microarthropods. 

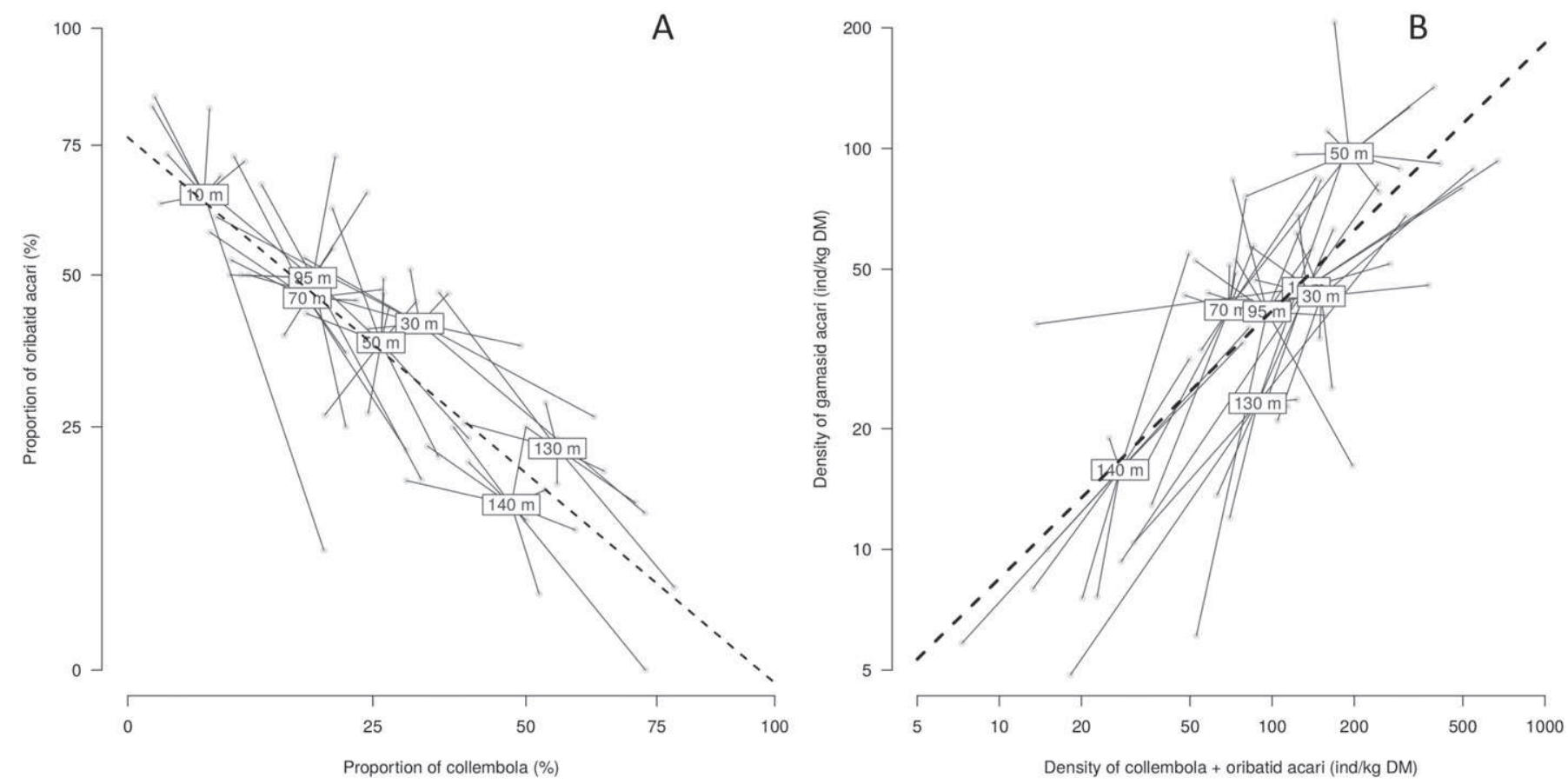

Fig. 3. (A) Proportion of oribatid mites compared to the proportion of springtails and (B) predator density (gamasid mites) compared to detritivorous density (oribatid mites and springtails). The proportion of oribatid mites decreases with the increasing proportion of springtails (power transform: $0.7 ; \mathrm{R}^{2}=0.68$ ). Predator density is proportional to the detritivorous density (log-transform; $\mathrm{R}^{2}=0.54$ ).

\subsection{Springtail community structure}

The distribution of springtail densities across species with respect to the distance to the factory is shown in Fig. 4. In total, 329 individuals of 18 different springtail species were identified at the site, with two species of suckers (Table 3 ). Four species were found in highly contaminated soils $(10 \mathrm{~m})$ and increased richness in diversity was found at larger distances (total of $11,15,13,11,13,10$ species at 30, 50, 70, 95, 130, $140 \mathrm{~m}$ respectively). Beta-diversity, here expressed as the number of species that differed between pairs of distances, decreased monotonically with increasing distance (10-30: 9; 30-50: 6; 50-70: 6; 70-95: 4; 95-130: 4; 130-140: 3; see Fig. 4). Juvenile springtails were underrepresented in highly contaminated soils $(10 \mathrm{~m})$.

\subsection{Metal accumulation in microarthropods}

$\mathrm{Pb}$ and $\mathrm{Cd}$ concentrations in springtails, oribatid and gamasid mites with respect to the distance to the factory are illustrated in Fig. S4. Bioaccumulation factors (BCF) for $\mathrm{Pb}$ and $\mathrm{Cd}$ are shown in Fig. 6. Eight BCF values at 70 and $95 \mathrm{~m}$ were discarded due to missing concentration data samples ( 3 out of 8 ) and extreme concentration values leading to higher BCF values $(0.65,4.17,0.99,1.91,1.14)$ than for the observed range. Pb BCF differed across groups and were constant across distances (2-way ANOVA on square root transformed BCF; group: $\mathrm{p}=10^{-6}$; distance: 0.065 ; group $\times$ distance: $\mathrm{p}=0.88$; $\mathrm{SW}: \mathrm{p}=0.18 ; \mathrm{BF}: \mathrm{p}=0.87$ ). Average $\mathrm{BCF}$ for springtails, oribatid and gamasid mites were (pooled over samples and distances) $0.13,0.24$, and 0.34 respectively. As illustrated in Fig. 6, $\mathrm{Pb} \mathrm{BCF}$ for gamasid mites was approximately equal to that for springtails plus twice the difference of the BCF between oribatid mites and springtails. $\mathrm{Cd} B C F$ were higher than those for $\mathrm{Pb}$ regardless of the distance from the factory, highlighting that $\mathrm{Cd}$ is more bioavailable than $\mathrm{Pb}$ in soil. The $\mathrm{Cd}$ BCF was always greater than 1 for the gamasid mites except at $10 \mathrm{~m}$ from the factory. Likewise, the $\mathrm{Cd}$ BCF was greater than 1 for oribatid mites and springtails at $70 \mathrm{~m}$ from the factory.

\section{Discussion}

4.1. Effect of soil pollution on the functional traits of microarthropod communities

4.1.1. Distribution of microarthropod groups with respect to soil pollution

The total density, as well as community structure, of microarthropods changed with respect to soil metal pollution and the $\mathrm{C} / \mathrm{N}$ ratio. Similar results were observed in previous studies (Gillet and Ponge, 2003; Cluzeau et al., 2012; Calugar, 2013). On the one hand, the total density of microarthropods is affected by the soil toxicity illustrated by the high toxic units decreasing with the distance to the factory (UT $=3212$ and 41 respectively 10 and $140 \mathrm{~m}$ from the factory). On the other hand, this result highlights the importance of organic matter content in soil for the development of microarthropod communities. As revealed by Neher et al. (2012), soil microfauna depends on the decomposition of organic residues and on the available nitrogen. Our results also showed a dominance of mites in the most contaminated areas, up to $100 \mathrm{~m}$ around the industrial site, where this group represented between 52 and 93\% of microarthropod density. In contrast, in areas of lower contamination $\left([\mathrm{Pb}]<1000 \mathrm{mg} \mathrm{kg}^{-1}\right)$, springtails were more abundant than mites with a distribution of microarthropod groups close to that observed in an open environment, e.g. in farming fields and grasslands (Cluzeau et al., 2012; Winkler and Toth, 2012). The mite community was essentially represented by oribatid mites, which suggests that detritivorous microarthropods (oribatid mites and springtails) were always more abundant than predators regardless of soil pollution levels. However, contrary to the observations of Calugar (2013), soil pollution does not seem to have an impact on gamasid mite density, which is largely present in the most polluted areas. Detritivorous microarthropods are the major group in the invertebrate biomass pyramid in most environments (Paoletti et al., 2007) and play a leading role in organic matter turnover. This is certainly why soil metal pollution influences both the $\mathrm{C} / \mathrm{N}$ and microarthropod distribution.

Detritivorous microarthropods also provide food for predator mites (Cluzeau et al., 2012; Paoletti et al., 2007; Caruso and Migliorini, 2006). Indeed, the positive correlation $\left(R^{2}=0.54\right)$ which was observed 


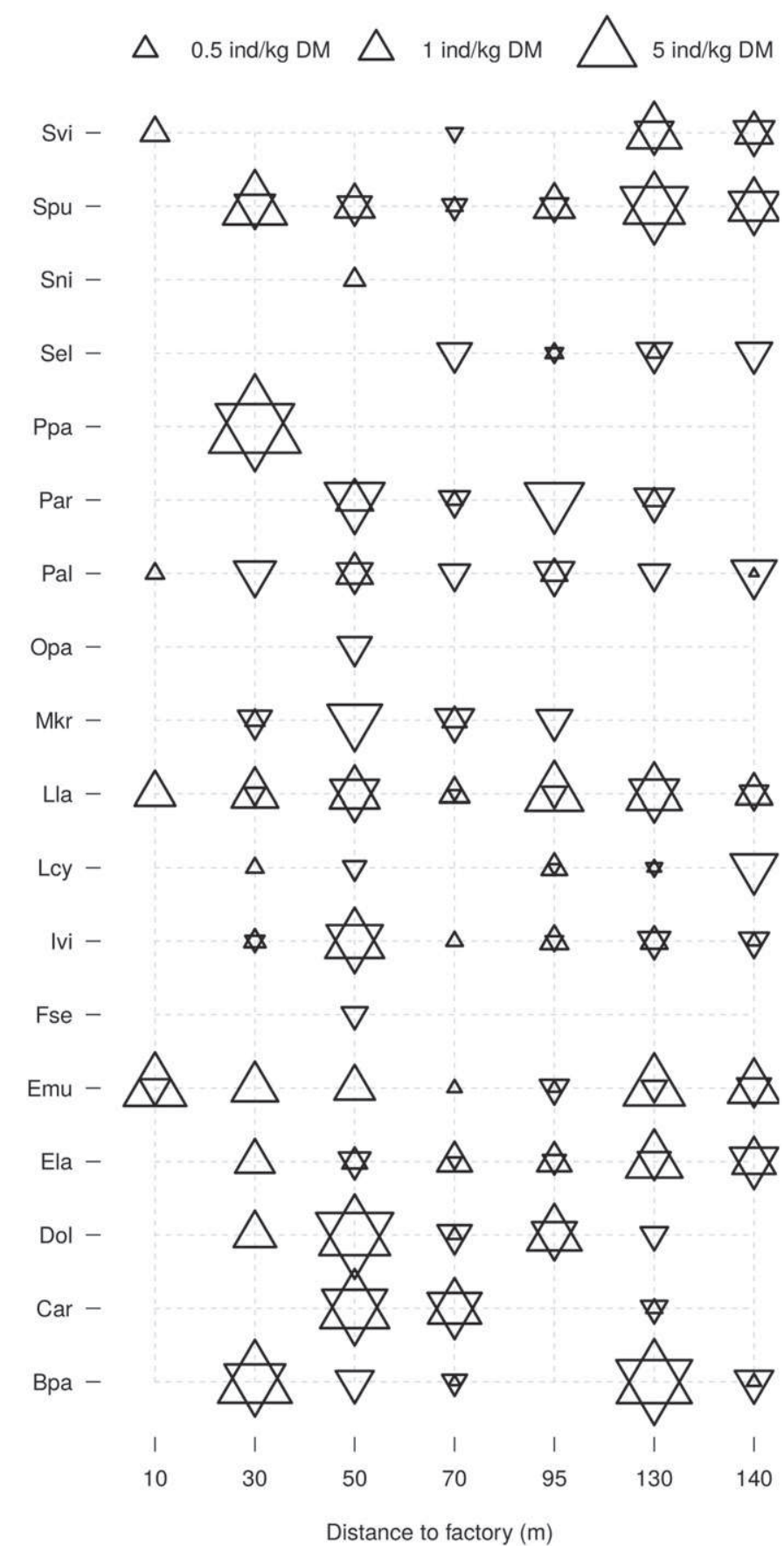

Fig. 4. Springtail densities in soil as a function of distance to the factory. Springtail densities - counts normalised to soil dry weight - are averaged over soil samples $(\mathrm{n}=10)$ and are represented as symbols (triangle up: adult; down: juvenile) the size of which is proportional to the log-density. Unabbreviated species names are shown in Table 3.

between the number of predator (gamasid mites) and detritivorous (oribatid mites and springtails) highlights the influence of the trophic level on the distribution of microarthropod communities. Detritivorous microarthropods, notably springtails, are the main prey of gamasid mites, so there is a balance between the number of detritivorous microarthropods and predators in the upper soil horizon. Similarly, the negative correlation $\left(R^{2}=0.68\right)$ between oribatid mite and springtail densities illustrates the concept of ecological niche (Lavelle et al., 2006). Such variations in microarthropod densities also appear to be dependent on soil macro-invertebrates, such as earthworms, whose diversity and abundance were measured at the site in a previous study, with a lower abundance and diversity in the most polluted areas (Levêque et al., 2015). In contrast, micraorthropod density is greater in heavily polluted soils than low polluted soils (located more than $100 \mathrm{~m}$ from the industrial site) and thus inversely proportional to soil macrofauna measured densities. Such a trend was previously observed in several studies (Salmon et al., 2005; Caruso et al., 2009; Hedde et al., 2012; Santorufo et al., 2014a, 2014b). Indeed, microarthropod abundance tends to be higher at polluted sites. This is at least partly due to the decrease of earthworm activity that induces superficial non-decomposed litter accumulation which then provides increased resource availability for litter mesofauna (Gutierrez-Lopez et al., 2010).

\subsubsection{Effect of metal(loid) pollution on springtail community structure}

Focussing on springtail community highlights an ecological response to environmental perturbations. Indeed, specific responses were observed in terms of species diversity. On the one hand, the number of encountered species was negatively correlated to metal pollution: with only 4 species in highly contaminated areas and more than 10 species found on low contaminated areas. This observation can be directly linked with the soil toxicity. At $10 \mathrm{~m}$, the toxic unit of soil was above 3200 and springtail richness was 4; at $140 \mathrm{~m}$, the toxic unit was 40 and 10 springtail species were listed. A study conducted near a former mining site in Poland (Syrek et al., 2006; Fiera, 2009) showed a similar trend. On the other hand, a decrease in sensitive species was observed in the contaminated area in the case of the genus Sminthurinus sp. and to a lesser extent Protaphorura armata and Ceratophysella armata (Winkler, 2014). Such a phenomenon promotes the development of ubiquitous species such as Lepidocyrtus lanuginosus, Mesaphorura krausbaueri, Entomobrya multifasciata and Pseudosinella alba (Fountain and Hopkin, 2004; Fiera, 2009; Santamaria et al., 2012; Winkler, 2014). These four species seem tolerant to metal soil pollution, as they were found throughout the entire study area. E. multifasciata and L. lanuginosus did not show significant changes in their numbers (except at $70 \mathrm{~m}$ from the industrial site) and represented close to 20 and $70 \%$ respectively of springtail communities in the most polluted soils. According to Syrek et al. (2006), the increase in the abundance of some springtail species subjected to environmental stress can be the result of released ecological niches. Springtails have the ability to make use of a wide spectrum of resources under competitive conditions which enable them to exploit resources more efficiently than competitors (Fountain and Hopkin, 2005, Winkler and Toth, 2012), and therefore to survive in polluted environments. A study by Gillet and Ponge (2003) of food contents in the guts of springtail species occurring in soils with different degrees of metal pollution showed that some species were able to select the less polluted food. For example, epigeic species, which were the most represented in the most polluted soils in our study, stopped feeding on fungi once they started accumulating trace metals and shifted their diet to hemi-organic humus (Syrek et al., 2006). Thus, the change in springtail ecological characteristics, observed here with respect to the distance to the industrial site, illustrates the behavioural adaptation of springtail populations to soil disturbance (Chagnon et al., 2000). As illustrated in Fig. S3C, the majority of springtail species at the site are of 'standard' and 'standard-to-explosive' reproductive types, with strong variations between both types. Species of 'explosive' reproductive type were found almost exclusively at $50 \mathrm{~m}$ and $70 \mathrm{~m}$ and species of 'parthenogenesis' type were found between $30 \mathrm{~m}$ and $95 \mathrm{~m}$. As illustrated in Fig. S3D, almost exclusively adult springtails were sampled at $10 \mathrm{~m}$ while farther away juveniles and adults were present with average proportions oscillating between 35\% and 65\%. Several authors (Skubała and Zaleski, 2012; Santamaria et al., 2012) have found that low metal concentrations are positively correlated with the development of microarthropod communities, and notably detritivorous, and with the stimulation on the rate of reproduction.

The CA of the springtail density data highlights the structure of the springtail community with respect to the distance to the factory 


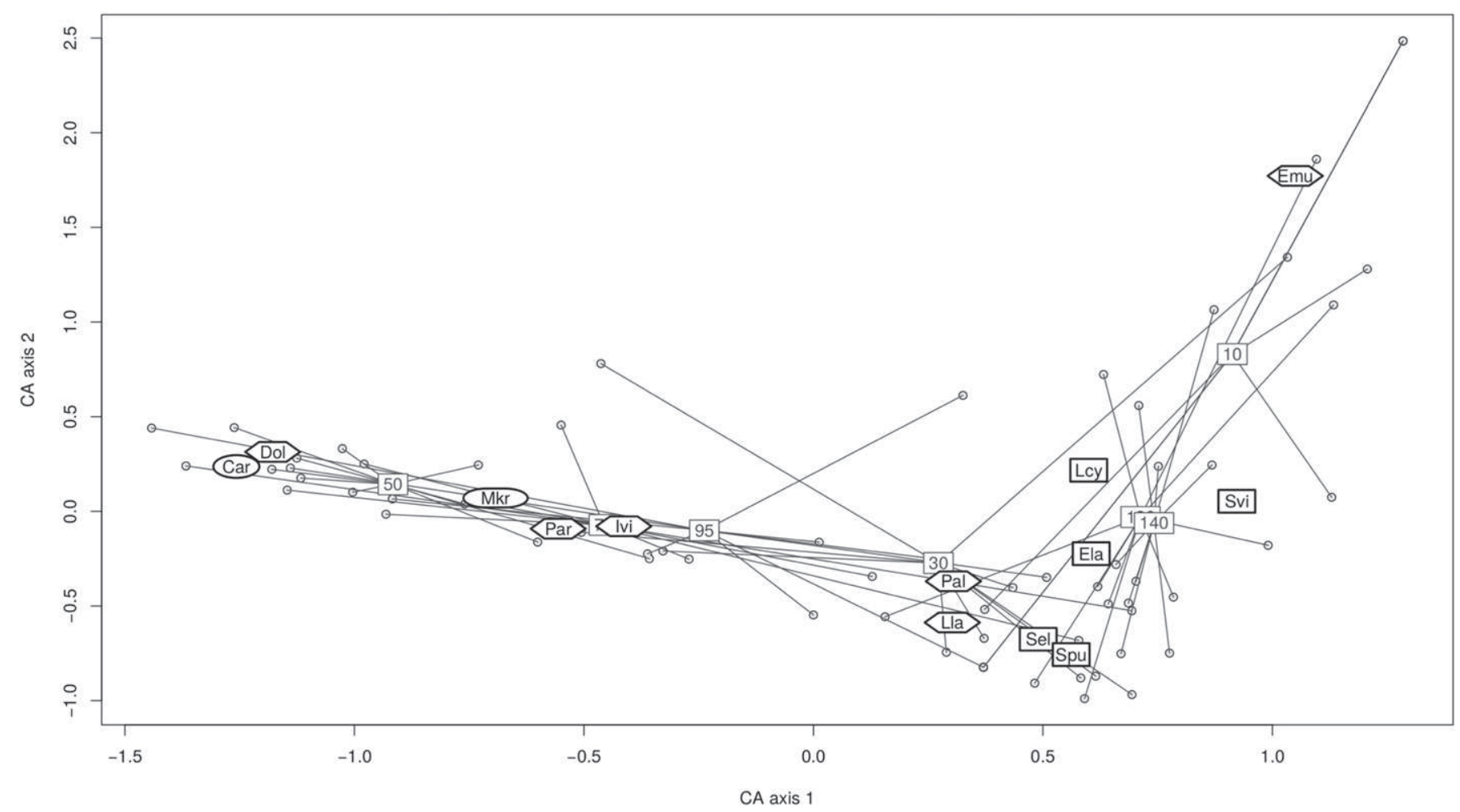

Fig. 5. CA joint plot (scaling type 1) of densities for grinder springtail species. Distance among soil samples in reduced space approximates their chi-squared distance (in this case, similarity of springtail community composition), soil samples found near a springtail species centroid has a high contribution to that species (in this case, soil samples contain that species), and species of close centroids are found in similar soil samples. Distance to factory of soil samples as well as species reproduction traits (rectangle: standard; hexagon: standard-to-explosive; ellipse: explosive; rounded rectangle: parthenogenesis) are highlighted in the plot. The first CA axis (21.1\% of the total inertia) discriminates reproduction traits from standard (Ela, Lcy, Sel, Spu, Svi; right side), standard-to-explosive (Dol, Emu, Ivi, Lla, Par, Pal; center), to explosive and parthenogenesis (Car, Mkr; left side).

(Fig. 5). The first two CA axes explained $19.0 \%$ and $15.3 \%$ of the total inertia, respectively, the joint plot of which is shown in Fig. S2. This plot shows that the first axis discriminates the species having 'suctorial' mouthparts called suckers (Brachystomella parvula and Pseudachorutes palmiensis: mostly found at $30 \mathrm{~m}$ ) from grinders (remaining species). These two species present the most important headcounts with respect
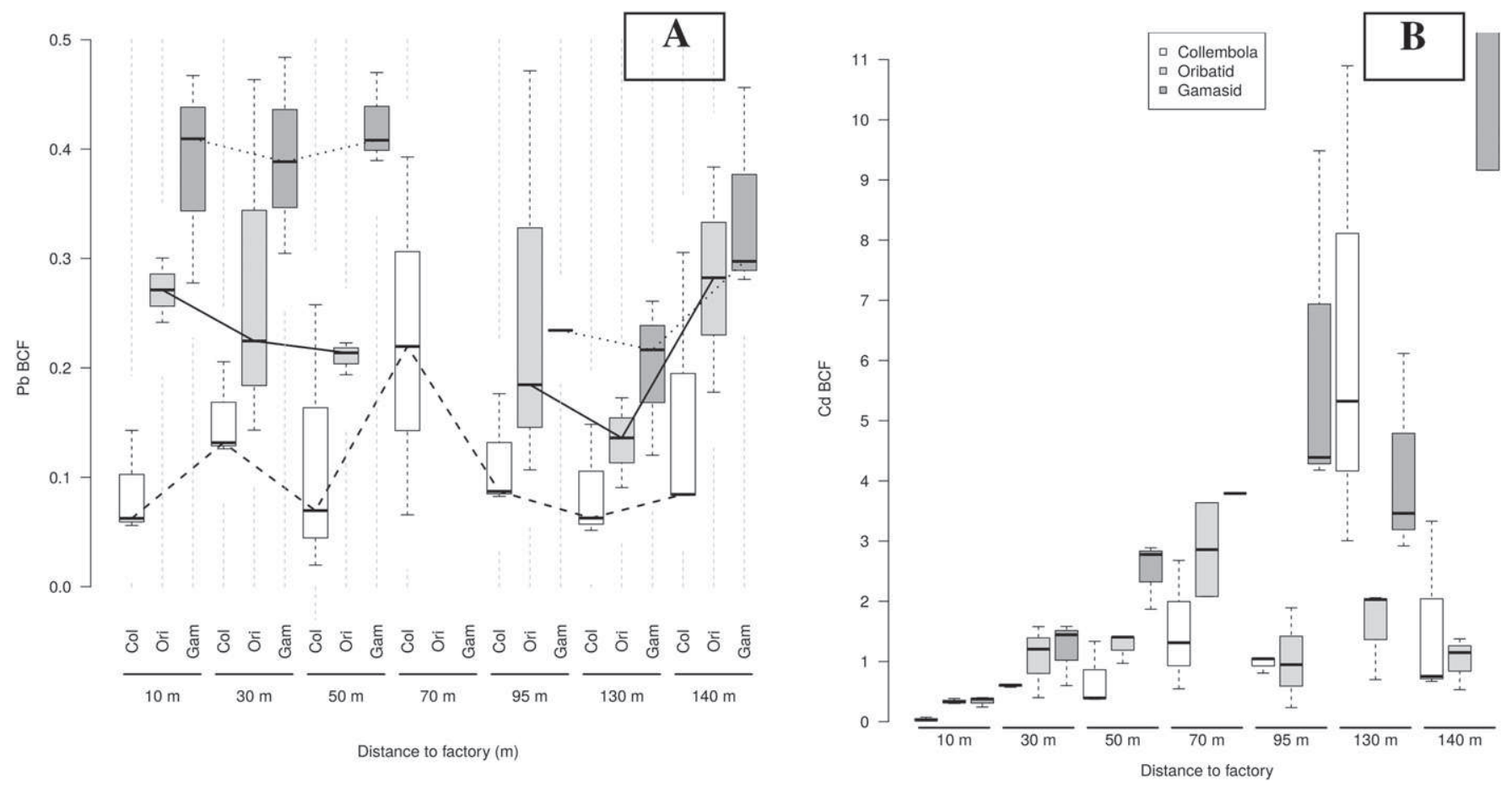

Fig. 6. Lead (A) and cadmium (B) bioaccumulation factors in microarthropods (Col: springtails; Gam: gamasid mites; Ori: oribatid mites) with respect to the distance to factory as box-and-whisker plots (median, upper and lower quartiles, and maximum values; 3 data samples per box). Outliers were discarded (see text). Medians are highlighted with lines (Springtail: dashed; Oribatid: solid; Gamasid: dotted). 
to all species identified in the site (Table 3). These results seem to indicate the importance of diet in the tolerance of metal pollution and changes of physico-chemical parameters of soil, notably nitrogen, highlighted in differents works (Chahartaghi et al., 2005; Larsen et al., 2008; Jorgensen et al., 2008; Hoskins et al., 2015). Otherwise, the presence of juvenile springtails $30 \mathrm{~m}$ from the factory seems to indicate the existence of mycorrhizal fungi essential to the springtail reproduction (Jorgensen et al., 2008; Hedenec et al., 2013; Hoskins et al., 2015) and principal feeding resource of sucker species, Brachystomella parvula and Pseudachorutes palmiensis. A second CA on springtail density data highlighted the structure of the remainder of the springtail community by excluding sucker species (B. parvula and P. palmiensis) as well as rare species (Folsomia sensibilis, Orogastrura parva, and Sminthurinus niger; See Table 3 for a definition of rare species). The first two axes explained $21.1 \%$ and $16.1 \%$ of the total inertia, respectively, and a joint plot is shown in Fig. 5. The first CA axis discriminates reproduction traits from standard (E. lanuginosa, Lepidocyrtus cyaneus, P. palmiensis, Sminthurinus elegans, Sphaeridia pumilis, Stenacidia violacea) to standard-to-explosive (Desoria olivacea, Isotoma viridis, L. lanuginosus, Protaphorura armata, Pseudosinella alba), explosive and parthenogenesis (Ceratophysella armata, M. krausbaueri). The ordination results are similar to those found above (Fig. S2), that is rare species as well as sucker species did not affect the ordination of more abundant, grinder species. All species with standard reproductive traits were found in similar samples (positive value for CA Axis 1). And, with the exception of E. multifasciata, all species with non-standard reproductive traits were also found in similar samples (negative value for CA Axis 1). These results show that reproduction strategies of springtails play a role in the springtail community distribution. Moreover, the very low presence of asexual reproduction, only one species $M$. krausbaueri, highlights the importance of sexual reproduction in the polluted environment and confirms the results of previous works (Santorufo et al. 2014a, 2014b; Salmon et al., 2014). Indeed, the asexual reproduction is a short term response in contrast to sexual reproduction which favours polymorphism and is thus an advantage to colonise an ecosystem disrupted like the polluted soils. This highlights the concept of balanced dynamics of ecosystems. Finally, the low ratio of juvenile/adult in very contaminated areas, up to $30 \mathrm{~m}$ of the factory, demonstrates the impact of soil toxicity on the reproductive capacity of springtails (Xu et al., 2009). Therefore, this study allowed for significant progress in understanding the diversity of environmental responses.

\subsection{Metal bioaccumulation across microarthropod groups}

We found a low level of lead bioaccumulation in microarthropods. Similar results were observed in Folsomia candida exposed to various polymetallic contaminated soils (Santorufo et al., 2012). Previous studies (Nursita et al., 2009; Ardestani et al., 2014) showed that the $\mathrm{Pb}$ and $\mathrm{Cd}$ concentrations in springtails reflect the soluble and easily exchangeable soil fraction. Moreover, the metal fraction bound to the soil organic matter, presenting an important percentage in the study soil, can affect the non-essential metal uptake rate by soil microarthropods (Nursita et al., 2009; Bur et al., 2012; Ardestani et al., 2014). In the studied polluted soil, high soil $\mathrm{pH}$ would decrease the solid-solution transfer of $\mathrm{Cd}$ and $\mathrm{Pb}$ and reduce their bioavailability as observed in the work carried out by Bur et al. (2012).

The $\mathrm{Pb}$ absorption rate of oribatid mites is significantly higher than for springtails. In addition, observing low variations in BCF in oribatids suggests a capacity to regulate $\mathrm{Pb}$ absorption. Skubała and Zaleski (2012) described this type of regulation for other toxic metals such as $\mathrm{Cd}$. However, these results show a high bioaccumulation capacity of $\mathrm{Cd}$ for oribatid and gamasid mites with BCF superior to 1 for the distance to factory more than $30 \mathrm{~m}$. Springtails seem to control the $\mathrm{Pb}$ and $\mathrm{Cd}$ absorption with BCF always less than 1 except at the distance of $130 \mathrm{~m}$ from the factory for $\mathrm{Cd}$. It should be noted that springtails are able to regulate their metal body content by eliminating absorbed metals (Ardestani and Van Gestel, 2014). Regulation does not concern essential metals such as $\mathrm{Cu}$ which some oribatid species have the ability to bioaccumulate with BCF $>10$ (Skubala and Kafel, 2004).

BCF comparison across the three groups of microarthropods showed that gamasid mites have the highest capacity for $\mathrm{Pb}$ and $\mathrm{Cd}$ bioaccumulation. One possible explanation is that gamasid mites are predators (Calugar, 2013) and so they are at a higher trophic level than detritivorous oribatid mites.

\section{Conclusions and perspectives}

Metal(loid) pollution had several impacts on microarthropod communities. Oribatid mite abundance increased while springtail richness and abundance decreased with increasing soil pollution. The abundance of gamasid mite communities, which were relatively stable with metal soil concentrations, suggested that there was an ecological equilibrium between populations, and certainly an ecological niche phenomenon.

$\mathrm{Pb}$ and $\mathrm{Cd}$ bioaccumulation depends on the total metal soil concentration and microarthropod characteristics such as maturity and species. In this study the influence of trophic level on $\mathrm{Pb}$ and $\mathrm{Cd}$ accumulation was also highlighted. For $\mathrm{Pb}$, bioaccumulation factors were low $(\mathrm{BF}<1)$ in highly polluted soils certainly due to exclusion/avoidance mechanisms and to low $\mathrm{Pb}$ bioavailability in soil.

Three springtail species, E. multifasciata, L. lanuginosus and P. alba, were always present regardless of the soil contamination level. These species may therefore be interesting "tools" as biotests to characterize soil ecotoxicity. This approach leads to a better understanding of the adaptation of springtail populations to metal soil pollution with a majority of epigeic species presenting 'standard' and 'standard-toexplosive' reproduction. In this way, our study demonstrated the interest of characterising the environmental impact of metal(loid) pollution in the field at the community scale. Examining both ecological and ecotoxicological changes in the entire microarthropod community is a global approach for environmental impact assessment of soil pollution.

\section{Acknowledgements}

The authors thank Leigh Gebbie for English review.

\section{Appendix A. Supplementary data}

Supplementary data to this article can be found online at http://dx. doi.org/10.1016/j.geoderma.2016.02.011.

\section{References}

Arbea, J.I., Jordana, R, 1997. Collembola, Poduromorpha, Familia Odentellidae y Familia Neanuridae In: Ramos, M.A. Lobo, J.M., Esteban, M. (Eds.), Fauna Ibérica vol. 8. Museo Nacional de Ciencas Naturales, CSIC, Madrid, pp. 233-477.

Ardestani, M.M., Van Gestel, C.A.M., 2013. Toxicodynamics of copper and cadmium in Folsomia candida exposed to simulated soil solutions. Environ. Toxicol. Chem. 32 (12), 2746-2754.

Ardestani, M.M., Van Gestel, C.A.M., 2014. The effect of pH and calcium on copper availability to the springtail Folsomia candida in simplified soil solutions. Pedobiologia 57 (1), 53-55.

Ardestani, M.M., VanStraalen, N.M., Van Gestel, C.A.M., 2014. Uptake and elimination kinetics of metals in soil invertabrates: a review. Environ. Pollut. 193, 277-295.

Austruy, A., Wanat, N., Moussard, C., Vernay, P., Joussein, E., Ledoigt, G., Hitmi, A., 2013. Physiological impacts of soil pollution and arsenic uptake in three plant species: Agrostis capillaris, Solanum nigrum, and Vicia faba. Ecotoxicol. Environ. Saf. 90, 28-34.

Berlese, A., 1905. Apparecchio per raccogliere presto ed in gran numero piccoli artropodi. Redia 2, 85-89.

Bretfeld, G., 1999. Synopses on Palaearctic Collembola, Volume 2. Symphypleona, Abhandlungen und Berichte des Naturkundemuseums Görlitz, Band 71, Heft 1. pp. 1-318.

BRGM, 2002 Gestion des sites (potentiellement) pollué - Version 2. Annexe 5C: Valeurs guides en matière de pollution des sols et des eaux. BRGM Edition, Orléans (13 pp.).

Bur, T., Crouau, Y., Bianco, A., Gandois, L., Probst, A., 2012. Toxicity of $\mathrm{Pb}$ and of $\mathrm{Pb} / \mathrm{Cd}$ combination on the springtail Folsomia candida in natural soils: reproduction, growth and bioaccumulation as indicators. Sci. Total Environ. 414, 187-197. 
Bur, T., Probst, A., Bianco, A., Gandois, L., Crouau, Y., 2010. Determining cadmium critical concentrations in natural soils by assessing Collembola mortality, reproduction and growth. Ecotoxicol. Environ. Saf. 73, 415-422.

Calugar, A., 2013. Effect of pollution with cement dust on the edaphic gamasid mite fauna (Acari: Gamasina) in different forest ecosystems from Romania. Acarologia 53 (2), $151-161$.

Caruso, T., Migliorini, M., 2006. Micro-arthropod communities under human distrubance: is taxonomic aggregation a valuable tool for detecting multivariate change? Evidence from Mediterranean soil aoribatid coenoses. Acta Oecol. 30, 46-53.

Caruso, T., Migliorini, M., Bucci, C., Bargagli, R., 2009. Spatial patterns and autocorrelation in the response of microarthropods to soil pollutants: the example of oribatid mites in an abandoned mining and smelting area. Environ. Pollut. 157, 2939-2948.

Chagnon, M., Hébert, C., Paré, D., 2000. Community structures of Collembola in sugar maple forests: relations to humus type and seasonal trends. Pedobiologia 44 (2), 148-174.

Chahartaghi, M., Langel, R., Scheu, S., Ruess, L., 2005. Feeding guilds in Collembola based on nitrogen stable isotope ratios. Soil Biol. Biochem. 37 (9), 1718-1725.

Chen, B., Snider, R.J., Snider, R.M., 1997. Mouthparts of three collembolan species: comparative morphology. Invertebr. Biol. 116 (4), 355-362.

Cluzeau, D., Guernion, M., Chaussod, R., Martin-Laurent, F., Villenave, C., Cortet, J., Ruiz-Camacho, N., Pernin, C., Mateille, T., Philippot, L., Bellido, A., Rougé, L., Arrouays, D., Bispo, A., Pérès, G., 2012. Integration of biodiversity in soil quality monitoring: baselines for microbial and soil fauna parameters for different land-use types. Eur. J. Soil Biol. 49, 63-72.

Coineau, Y., Cleva, R., Du Chatenet, G., 1997. Ces animaux minuscules qui nous entourent. Delachaux et Niestlé Ed, Paris (77 pp.).

Coleman, D.C., Crossley Jr., D.A., Hendrix, P.F., 2004. Fundamentals of Soil Ecology. second ed. Elsevier Academic Press, San Diego, US (386 pp.).

Czarnetzki, A.B., Tebbe, C.C., 2004. Detection and phylogenetic analysis of Wolbachia in Collembola. Environ. Microbiol. 6 (1), 35-44.

Dumat, C., Austruy, A., 2014. Phytotechnologies pour la gestion des sols pollués par les métaux. Gestion des sites et sols pollués. Technique de l'Ingénieur Ed., Paris (19 pp.).

Edward, C., Fletcher, K., 1971. A comparison of extraction methods for terrestrial arthropods. In: Phillipson, J. (Ed.), Methods of Study in Quantitative Soil Ecology: Population, Production and Energy Flow. Blackwell Scientific Publication, Oxford, pp. $150-185$.

Fiera, C., 2009. Biodiversity of Collembola in urban soils and their use as bioindicators for pollution. Pesq. Agrop. Brasileira 44 (8), 868-873.

Fountain, M.T., Hopkin, S.T., 2005. Folsomia candida (Collembola): a standard soil arthropod. Annu. Rev. Entomol. 50, 201-222.

Fountain, M.T., Hopkin, S.T., 2004. Biodiversity of Collembola in urban soils and the use of Folsomia candida to assess soil ‘quality'. Ecotoxicology 13, 555-572.

Gichner, T., Patková, Z., Száková, J., Žnidar, I., Mukherjee, A., 2008. DNA damage in potato plants induced by cadmium, ethyl methanesulphonate and $\gamma$-rays. Environ. Exp. Bot. 62, 113-119.

Gillet, S., Ponge, J.F., 2003. Changes in species assemblages and diets of Collembola along a gradient of metal pollution. Appl. Soil Ecol. 22, 127-138.

Gisin, H., 1943. Oekologie und Lebensgemeinschaften der Collembolen im Schweizerischen Excursionsgebiet Basels. Rev. Suisse Zool. 50, 131-224.

Gis Sol, 2011. L'état des sols de France. Groupement d'intérêt scientifique sur les sols (188 pp.

Gobat, J.M., Aragno, M., Matthey, W., 2010. The Living Soil: Fundamentals of Soil Science and Soil Biology. Science Pub Ing Ed, Lausanne (602 pp.).

Gutierrez-Lopez, M., Jesus, J.B., Trigo, D., Fernandez, R., Novo, M., Diaz-Cosin, D.J., 2010. Relationships among spatial distribution of soil microarthropods, earthworm species and soil properties. Pedobiologia 53 (6), 381-389.

Hedde, M., Van Oort, F., Lamy, I., 2012. Functional traits of soil invertebrates as indicators for exposure to soil disturbance. Environ. Pollut. 164, 59-65.

Hedenec, P., Radochova, P., Novalova, A., Kaneda, S., Frouz, J., 2013. Grazing preference and utilization of soil fungi by Folsomia candida (Isotomidae:Collembola). Eur. J. Soil Biol. 55, 66-70.

Hernandez, L., Probst, A., Probst, J.L., Ulrich, E., 2003. Heavy metal distribution in some French forest soils: evidence for atmospheric contamination. Sci. Total Environ. 312, 195-219.

Hishi, T., Takeda, H., 2008. Soil microarthropods alter the growth and morphology of fungi and fine roots of Chamaecyparis obtusa. Pedobiologia 52 (2), 97-110.

Hopkin, S.P., 1997. Biology of the Springtails. Oxford University Press, Oxford (340 pp.).

Hoskins, J.L., Janion-Scheepers, C., Chown, S.L., Duffy, G.A., 2015. Growth and reproduction of laboratory-reared neanurid collembola using a novel slime mould diet. Sci. Rep. 5, 11957. http://dx.doi.org/10.1038/srep11957.

Jorgensen, H.B., Hedlund, K., Axelsen, J.A., 2008. Life-history traits of soil collembolans in relation to food quality. Appl. Soil Ecol. 38 (2), 146-151.

Kpan, J.D.A., Opoku, B.D., Gloria, A., 2014. Heavy metal pollution in soil and water in some selected towns in Dunkwa-on-Offin District in the Central Region of Ghana as a result of small scale gold mining. J. Agric. Chem. Environ. 3, 40-47.

Lanno, R., Wells, J., Conder, J., Bradham, K., Basta, N., 2004. The bioavailability of chemical in soil for earthworms. Ecotoxicol. Environ. Saf. 57, 39-47.

Larsen, J., Johansen, A., Larsen, S.E., Heckmann, L.H., Jakobsen, I., Krogh, P.H., 2008. Soil Biol. Biochem. 40 (2), 360-369.

Lavelle, P., Decaëns, T. Aubert, M., Barot, S., Blouin, M., Bureau, F., Margerie, P., Mora, P., Rossi, J.P., 2006. Soil invertabrates and ecosystem services. Eur. J. Soil Biol. 42, 3-15.

Levêque, T., Capowiez, Y., Schreck, E., Mazzia, C., Auffan, M., Foucault, Y., Austruy, A., Dumat, C., 2013. Assessing ecotoxicity and uptake of metals and metalloids in relation to two different earthworm species (Eiseina hortensis and Lumbricus terrestris). Environ. Pollut. 179, 232-241.
Levêque, T., Capowiez, Y., Schreck, E., Mombo, S., Mazzia, C., Foucault, Y., Dumat, C., 2015. Effect of historic metal(loid) pollution on earthworm communities. Sci. Total Environ. $511,738-746$

Massoud, Z., 1967. Monographie des Neanuridae, Collemboles Poduromorphes a pièces buccales modifiées. Biologie de l'Amérique Australe vol. 3. CNRS Ed., Paris, pp. 7-399.

Neher, D.A., Weicht, T.R., Barbercheck, M.E., 2012. Linking invertebrate communities to decomposition rate and nitrogen availability in pine forest soils. Appl. Soil Ecol. 54, 14-23.

N'guessan, Y.M., Probst, J.L., Bur, T., Probst, A., 2009. Trace elements in stream bed sediments from agricultural catchments (Gascogne region, S-W France): where do they come from? Sci. Total Environ. 407, 2939-2952.

Nursita, A.I., Singh, B., Lees, E., 2009. Cadmium bioaccumulation in Proisotoma minuta in relation to bioavailability in soils. Ecotoxicol. Environ. Saf. 72, 1767-1773.

Paoletti, M.G., Osler, G.H., Kinnear, A., Black, D.G., Thomson, L.J., Tsitsilas, A., Sharley, D. Judd, S., Neville, P., D'Inca, A., 2007. Detritivorous as indicators of landscape stress and soil degradation. Aust. J. Exp. Agric. 47 (4), 412-423.

Potapov, M., 2001. Synopses on Palaearctic Collembola, Volume 3. Isotomidae, Abhandlungen und Berichte des Naturkundemuseums Görlitz, Band 73, Heft 2, 2001. pp. 1-603.

R Core Team, 2014. R: A Language and Environment for Statistical Computing. R Foundation for Statistical Computing, Vienna, Austria.

Redon, P.O., Bur, T., Guiresse, M., Probst, J.L., Toiser, A., Revel, J.C., Jolivet, C., Probst, A. 2013. Modelling trace metal background to evaluate anthropogenic contamination in arable soils of south-western France. Geoderma 206, 112-122.

Reddy, A.M., Kumar, S.G., Jyothsnakumari, G., Thimmanaik, S., Sudhakar, C., 2005. Lead induced changes in antioxidant metabolism of horsegram (Macrotyloma uniflorum (Lam.) Verdc.) and bengalgram (Cicerarietinum L.). Chemosphere 60 97-104.

Rusek, J., 1971. Zur Taxonomie der Tullbergia (Mesaphorura) krausbaueri (Börner) und ihrer verwandten (Collembola). Acta Entomol. Bohemoslov. 68 (1971) 188-206.

Salmon, S., Geoffroy, J.J., Ponge, J.F., 2005. Earthworms and collembola relationships: effects of predatory centipedes and humus forms. Soil Biol. Biochem. 37, 487-495.

Salmon, S., Ponge, J.F., Gachet, S., Deharveng, L., Lefebvre, N., Delabrosse, F., 2014. Linking species, traits and habitat characteristics of Collembola at European scale. Soil Biol. Biochem. 75, 73-85.

Santamaria, J.M., Moraza, M.L., Elustondo, D., Baquero, E., Jordana, R., Lasheras, E. Bermejo, R., Arino, A.H., 2012. Diversity of acari and collembola along a pollution gradient in soils of a pre-Pyrenean forest ecosystem. Environ. Eng. Sci. 11 (6), $1159-1169$

Santorufo, L., Cortet, J., Arena, C., Goudon, R., Rakoto, A., Morel, J.L., Maisto, G., 2014a. An assessment of the influence of the urban environment on collembolan communities in soils using taxonomy and trait based approaches. Appl. Soil Ecol. $78,48-56$.

Santorufo, L., Van Gestel, C.A.M., Maisto, G., 2014b. Sampling season affects conclusions on soil arthropod community structure responses to metal pollution in Mediterranean urban soils. Geoderma 226-227, 47-53.

Santorufo, L., Van Gestel, C.A.M., Rocco, A., Maisto, G., 2012. Soil invertebrates as bioindicators of urban soil quality. Environ. Pollut. 161, 57-63.

Schreck, E., Foucault, Y., Geret, F., Pradere, P., Dumat, C., 2011. Influence of soil ageing on bioavailability and ecotoxicity of lead carried by process waste metallic ultrafine particles. Chemosphere 85 (10), 1555-1562.

Sechi, V., D'Annibale, A., Ambus, P., Sárossy, Z., Krogh, P.H., Eriksen, J., Holmstrup, M., 2014. Collembola feeding habits and niche specialization in agricultural grasslands of different composition. Soil Biol. Biochem. 74, 31-38.

Shahid, M., Austruy, A, Echevarria, G, Arshad, M., Sanaullah, M., Aslam, M., Nadeem, M Nasim, W., Dumat, C., 2014. EDTA-enhanced phytoremediation of heavy metals: a review. Soil Sediment Contam. 23 (4), 389-416.

Sharma, P., Dubey, R.S., 2005. Lead toxicity in plants. Braz. J. Plant Physiol. 17, 35-52.

Skubala, P., Kafel, A., 2004. Oribatid mite communities and metal bioaccumulation in oribatid species (Acari, Oribatida) along the heavy metal gradient in forest ecosystems. Environ. Pollut. 132, 51-60.

Skubała, P., Zaleski, T., 2012. Heavy metal sensitivity and bioconcentration in oribatid mites (Acari, Oribatida): gradient study in meadow ecosystems. Sci. Total Environ. 414, 364-372.

Sterckeman, T., Douay, F., Baize, D., Fourrier, H., Proix, N., Schwart, C., 2006. Trace elements in soils developed in sedimentary materials from Northern France. Geoderma 136, 912-929.

Syrek, D., Weiner, W., Wojtylak, M., Olszowska, G., Kwapis, Z., 2006. Species abundance distribution of collembolan communities in forest soils polluted with heavy metal. J. Appl. Ecol. 31, 239-250.

Thibaud, J.-M., Schulz, H.J., Da Gama Assalino, M.M., 2004. Synopses on Palaearctic Collembola, Volume 4. Hypogastruridae., Abhandlungen und Berichte des Naturkundemuseums Görlitz, Band 75, Heft 2. pp. 1-287.

Tully, T., Ferriere, R., 2008. Reproductive flexibility: genetic variation, genetic costs and long-term evolution in a collembola. PLoS One 3 (9), e3207.

Van Eekeren, N., Van Liere, D., De Vries, F.T., Rutgers, M., De Goede, R.G.M., Brussaard, L, 2009. A mixture of grass and clover combines the positive effects of both plant species on selected soil biota. Appl. Soil Ecol. 42, 254-263.

Van Gestel, C., Koolhaas, J., 2004. Water-extractability, free ion activity, and pH explain cadmium sorption and toxicity to Folsomia candida (Collembola) in seven soil-pH combinations. Environ. Toxicol. Chem. 23, 1822-1833.

Wall, D.H., Bardgett, R.D., Behan-Pelletier, V., Herrick, J.E., Jones, T.H., Six, J., Strong, D.R., Van der Putten, W.H., 2013. Soil Ecology and Ecosystem Services. Oxford University Press, Oxford (424 pp.) 
Wang, W.X., Rainbow, P.S., 2008. Comparative approaches to understand metal bioaccumulation in aquatic animals. Comp. Biochem. Physiol. C 148 (4), 315-323.

Winkler, D., 2014. Collembolan response to red mud pollution in Western Hungary. Appl. Soil Ecol. 83, 219-229.

Winkler, D., Toth, V., 2012. Effects of afforestation with pines on collembola diversity in the limestone hills of Szarhalom (West Hungary). Acta Silvatica Lignaria Hung. 8 (1), 9-20.
Xiong, T., Levêque, T., Austruy, A., Goix, S., Schreck, E., Dappe, V., Sobanska, S., Foucault, Y Dumat, C., 2014. Foliar uptake and metal(loid) bioaccessibility in vegetables exposed to particulate matter. Environ. Geochem. Health 36, 897-909.

Xu, J., Xin, K., Krogh, P.H., Wang, Y., Luo, Y.M., Song, J., 2009. Evaluation of growth and reproduction as indicators of soil metal toxicity to the collembolan, Sinella curviseta. Insect Sci. 16, 57-63. 